\title{
Politics, Received Knowledge and the Subordination of indigenous Creativity
}

\author{
Akinpelu O. Olutayo \\ Department of Sociology, \\ University of Ibadan, Ibadan \\ lantopamtu@yahoo.com
}

DOI: $10.36108 / \mathrm{NJSA} / 8002 / 60(0160)$

Vol. 6 Issue 1, 2008

\begin{abstract}
All societies had their own pattern of development embedded in the means of exploitation of the environment around which certain social institutions were created to satisfy the 'needs' of the people. The colonial epoch, with its own needs, substituted the 'needs' of the colonized with its own and recommended new ways of satisfying these new needs. This process is still being recommended through the pattern of domination in 'world institutions' manifested through new 'indigenous' social institutions in the neo-colonial African states. Of utmost significance are the formal educational institutions, through which the political elites are created, characterized by a privileged status and a culture of subordination. The understanding of the underdevelopment process and its perpetuation in Africa cannot, therefore, be deciphered without an in-depth knowledge of the politics of colonialism, embedded in the 'worldview' of received knowledge from the (neo-) colonizing authorities, and enhanced through the subordination of indigenous creativity. In order words, the disjuncture in what constituted knowledge and creativity in the pre-colonial arrangement and that expected in the received domain, is the crux of transformation in Africa. How can Africa catch-up with the phenomenal movement of this airplane?
\end{abstract}

Key words: politics, received knowledge, indigenous creativity, colonial intervention, development

\section{Introduction}

Early in the 1980s, Raul Prebisch identified, in international economy, what he called "the return of the orthodoxy" as witnessed in the recommendation of the Breton Woods Institutions' reform packages for developing nations in the generalization of poverty (Boron, 2004). Within this renewal, in the neo-liberal approach, it is not only the market that returns to the centre-stage but ideas based on the unilateral explanation of socio-structural arrangements of the world. And its history dates back to the emergence of the World Capitalist Economy (WCE). Especially for Africa, its incorporation into the WCE signaled the end of independent development and a re-structuring of the society. It meant, for the colonizing governments, a civilization in which case what they might have achieved in terms of knowledge of how things should be done and general ways of life were subordinated to the colonizing ways of doing things. Whether it was (and still is) the family- which used to be in form of extended networks in enhancing the cultivation of much land, the possession of more than one wife through whom many children would be secured for the 
exploitation of land, respect for the elderly due to their possession of the knowledge of the environment among others (Olutayo, 1994); or the informal education which gives holistic knowledge including initiation rites differentiated between males and females and their eventual socialization into their respective occupations having learnt, day-in-day-out, from their parents through meaningful symbolic gestures and learning by practice; or political arrangements based on indigenous checks and balances as well as the economic institutions for exploiting the environment based on sustainable understanding. All of these had (and is still) to change to 'received knowledge' informed by other people's experiences.

Fundamentally, 'science' has become the norm understood in terms of the only answer to all things. And in this science, what reigns supreme is 'rationality'/reason. In this reasoning is the necessity of providing 'empirical evidence' for whatever knowledge is to be provided and, therefore, all other knowledge are non-rational or, even, irrational. Now, the growth of this science, in Europe, has been with them since about the $4^{\text {th }}$ century extending roughly from the introduction of Aristotle's works into the nascent universities to the birth of the modern scientific method and the origins of the scientific worldview (Kreis, 2007a). The scientific methodology came about as a result of what is often referred as the scientific revolution involving the way the individual perceives the world changing human thought processes. It was an intellectual revolution in human knowledge that resulted from the overturning of supernatural and metaphysical explanation for social order. As Kreis (2007b) observed, the revolutionaries had to escape their intellectual heritage to create a watershed in history. Science is about:

...everything we see, touch, smell, hear... Furthermore, science has a language all its own, a language which uses expressions like: rational, method, methodological, systematic, rules, laws, behavior, experts, technology and so on. (Kreis 2007b: p.2)

Yet, science is an idea that gives us a perspective of ways to think about and explain our world and ourselves. This perspective is a product of the historical experience of certain parts of the world that generated how to solve what they perceived of their needs in their environments. It entailed the creation of a way of life fashioned around a type of social structure relevant to their socio-economic and political situation. With time, it subsumed emotions, dreams, joy, sadness, successes and failures as variables that can be measured and controlled for. Interestingly, and in spite of all its achievements all around, science could not control for World wars and the callous destruction of human lives; it has not solved the problems of hunger and poverty, sustainable agriculture and environmental justice as well as public health and, as Randeria (2005) observed, would still be with us in the year 2030.

Yet, it was the advance of science of technology in Europe that informed both the politics of national development and economic growth as well as the 
establishment of imperial powers abroad and the eventual reinstatement of the politics of development in neo-colonial regimes. In its new garb, the free market economy of ideas is assumed to predominate even when knowledge production has become more dominant in one part of the world over others. According to Bourner (1998), the Carnegie Foundation report on "Higher Education and the American Resurgence" recorded that the number of scientific and technical book titles published in the USA had grown from 3,000 in 1960 to 15,000 in 1980 and, by 1986, he says, Times Higher Education Supplement reported that 50,000 book titles (all subjects) were being published in Britain alone and about 7,000 scientific articles were daily being published worldwide-definitely more than $80 \%$ in the USA and Europe. Indeed, Altbach (2007) has shown that English language is the dominant language in the world thus dictating the language of science, scholarship, and instruction like never before. He found that there are more students studying English in China than are studying in the United States and more speakers of English in India than in Britain. English, he noted, has an officially recognized status in more than 70 countries to which was given stimulus by colonialism since the $18^{\text {th }}$ century. Today, no African university offers instruction in any indigenous African language. Thus, English language dominates scientific and scholarly journals such that research paradigms and scholarly interests of the journal editors, editorial board members, and even the majority of readers control journals and the research agendas and methodologies in most disciplines to which scholars in other parts of the world are made to conform, if they want to publish their findings.

Of course, all of these are mainly for consumption for the whole world containing a certain worldview of the writers. Unfortunately, they are also supposed to be received and form the basis of knowledge in the receiving nation as Cross-Border education is already doing, for example (Knight, 2006) and the transition to the so called global knowledge society with core values of what has been defined as 'the essence of academic education' comprising of the values related to the rules of knowledge creation, such as independent and 'critical' research, the 'open' nature of the scientific research system, the epistemological and methodological principles of 'sound research', the notion of 'scholarship' and 'quality' of education ( Van Damme, 2002: p.12), all of which reject indigenous knowledge structures. It is no longer an era of criticism where other points of view would be placed beside sharp blade of scrutiny or the criticism that formed the core of the $18^{\text {th }}$ century Enlightenment thought. Science is now faith backed by 'reason' within a framework of what is labeled 'objectivity', 'openness' or 'transparency', 'predictability' and causal relations, among others. Consequently, knowledge for innovations and creativity has to be seen within this view or else, it is not knowledge more so where traditional idiosyncrasies are not clearly understood. In fact, there is no longer enough time to attempt to understand these idiosyncrasies as developing societies are pressured to change based on the pace of the developed nations of the world in the so called 'United Nations' (UN). In the major dominating 
stance is the fact that the curriculum is also dominated by the English language; the academic journals and books, as Altbach (2007) further observed, are published in English and edited from the United States and the United Kingdom; and these publications are almost the only ones internationally circulated. With these, the norms, values, methodologies, and orientations of the academic communities in the centers dominate the rest of the World. And, because knowledge is ranked by the level of recognition by the international academic communities, domestic publications, which may be relevant to domestic needs, are unrecognized. This is probably one of the reasons why, in 1995, Sub-Saharan Africa published only 5,839 academic papers (while South Asia produced 15,995 and Latin America and the Caribbean produced 14,426) (Bloom, Canning \& Chan, 2006). It is not surprising, therefore, that ideas for development are dictated from the centers to which the peripheries are, more or less, forced to adopt even in these other regions of the world. For all of them, the orientation is how to catch-up with the world centers of knowledge in the U.S and Western Europe.

The United Nations Organization, especially through its agencies like the World Bank and the IMF, now determines the pace at which the peripheral nations have to 'run'. For instance, the World Bank, after so many years of neglecting and, in fact, jettisoning the relevance of tertiary education to development, suddenly woke up to the realization of its importance to economic development in its Knowledge for Development publication of 1998/99, creating Knowledge Economy Index (KEI) benchmarking four aspects of knowledge economy and, of course, Africa scored the least in the index comprising of economic and institutional regime, education, innovation and the information and communications technologies. The MDGs are only one of the new recommendations for measuring development. Yet, around 1998, the World Bank acknowledged, it seemed, the fact that '(r)ural people in Africa have always maintained a certain formidable power that guards their indigenous institutions and knowledge systems, thereby maintaining some level of self-reliance' and that Africans are informed innovators (Donnelly-Roark, 1998, Nwokeabia, 2006) and thus the resistance of Africa to externally induced development projects and practices.

Ironically, and in spite of the pictures showing positive economic growth in the last three years and increased spending on poverty reduction by providing critical government services, based on the recommendation of World Bank institutions, Sub-Saharan Africa (SSA) still has a long way to go in meeting the MDGs! (IMF Survey Online, 2007). Though social and other obstacles have been identified as affecting the meeting of non-income MDGs, it is also a fact that SSA depends on the foreign demands for its performance, the shocks from which may destabilize all supposed gains (DEAS, 2006). Indeed, as the IMF Survey, as shown by Mauro and Ostry (2007), attests, and in spite of moderate increases from low- and middle-income countries, it is the high income countries that are driving financial globalization. In fact, in the words of this survey, 'bilateral, gross asset holdings are closely associated with 
factors such as distance, language, and former colonial links'. Perhaps, there is no gainsaying the fact that even the language is still a colonial heritage. Thus, the beat still goes on in the return to the continued suppression of SSA nations as their ability to create knowledge and innovate is continuously stifled! But why does this process appear to be in perpetuity? And how can this chain be broken?

To answer these questions, the remaining parts of the paper are divided into four sections. The next question addresses the basis of creativity and knowledge creation in pre-colonial Africa showing how the social, economic and political networks enhanced production and its improvements tied around certain socio-structural arrangements. The next section exposes the incorporation of Africa into the WCE and the eventual subordination of this creativity through the creation of a new structure in contradistinction from the basis of existence in Africa as well as how this has been used to perpetuate domination. In the third section, attempt is made to recommend how these nations can realize their existence even in the WCE and the final section concludes the paper.

\section{Knowledge and Creativity in Pre-Colonial Africa}

Just as the emergence of knowledge in 'science' has been traced to the great philosophers of the $4^{\text {th }}$ century, and its 'purifications' in the their followers' questionings, leading to modifications, the generic corpus of knowledge in almost all of pre-colonial Africa, as Guyer (1996:6) stated, in her discussion of Equatorial Africa, 'was embedded in ancestral realities as well as in the living, and new and particular compositions...embodied in certain "things" ". And the 'knowledge' (as explicated by Kopytoff, 1981 as different from 'belief' in) of the ancestors was not just about what happened in the life hereafter, but their social role in this world. Thus, the knowledge that the minkisi among the peoples of Equatorial Africa or the Eleda among the Yoruba of South West Nigeria punishes when one misbehaves or annoys him or looks after one is a reality to the peoples in these regions which informs their behavior towards each other. It is a knowledge that does not need to be 'proved' based on the experiences that inform the 'knowledge'. The expectations from the ancestors are never ever static as the itan which inform them are always dynamic illuminating, enlightening, discerning and entangling or even de-riddling, by shedding light on human existence in chronological dimensions of human generations and/or territorial and geographical expansion thus presenting changes in human existence (Yai, 1993).

In ensuring conformity as well as showing expected changing patterns, the norms and values governing every aspect of human life is given existence in social, economic and political relations. Thus, the duties and obligations of the elder were not to exploit or lord it over the subordinates (Olutayo, 1996) neither were economic activities undertaken based on lineage and ancestors or without certain thought processes. Just as Fred-Mensah (2003) has shown the Buem's adzina system of trial by jury on the Ghana-Togo border involving the 
choosing of the jury only after everyone had heard the case instead of before, to preclude bias, Leonard (2001), has also shown the economics of healing among African traditional healers to involve an outcome-contingent approach through which they make more than the modern practitioners' effort-contingent method. As Silver (1981) has shown, among the Ashanti Carving Community, risks are calculated and some socioeconomic categories of carvers produce more creative innovators than others due to the practical needs within the local socioeconomic milieu. Indeed, what this implies is that innovators create based on the need generated for them and the need in the socio-cultural environment resulting, therefore, in carvings for different hierarchical groups, even in the display of wealth manifest on doors and construction of palaces. These carvers, as Silver (1981:p.105) found out, show ingenuity not only by 'gifts' from the ancestors but also because

...they also possess a facility for concentration which far exceeds their peers. They claim to think deeply about their work, constantly searching for more effective ways to "tease out" messages from the wood. In fact, such special skills may earn carvers honorific titles and, in some cases, extra responsibilities and privileges.

Indeed, Austen and Headrick (1983) have identified three stages of technological development in Africa, with the use of archeological recovery and analysis of remains of utensils, habitats, animals and plants and, taking cognizance of peculiar African situation. The first stage, with which we are concerned here, was the fairly rapid and autonomous emergence and spread of what they called "classical African agricultural and metal-using technologies". During this stage, the first domesticated plants in Africa (sorghum, millet, rice, yam, oil palm) were found to be indigenous to the sub-Saharan region. In fact, iron metallurgy was found to have dated back to 500B.C in some parts of Sudan, Nigeria, and Tanzania and, by 3,000 A.D, Africans could support themselves in farming and animal husbandry. In these endeavours, ironmaking, through mining, smelting and fabrications, developed with agriculture indigenously with the craft rapidly spreading and 'reaching a level of sophistication which rivaled contemporary European and Middle Eastern metallurgy in at least its smelting processes' (Austen \& Headrick, 1983:p.166). African smelting was, in fact, said to be technologically in advance of Europe, Middle Eastern or Southern Asian smelting. With these instruments, new crops from Asia (banana, cocoyams, cotton) and the New World (maize, manioc, peanuts, sweet potato) were domesticated and added to the African food production systems leading to commercialization of food production in various regions. Manufacturing tools were developed for the production of clothing with hand-looms and the spindle (Olutayo, 1991). Canoes were indigenously manufactured, up to 80 feet in length, for carrying human beings and products of trade both for inland waters and several miles out at sea for trading along the coast. In short, depending on the mastery of its environment, Africans created 
knowledge, through indigenous innovations and adaptations, for the satisfaction of what they considered their needs within their own socio-structural arrangements for which they did not need to make apologies for anyone.

At the second stage, identified by Austen and Headrick, Africans, based on the understanding of their social, political and economic situations, and after a long period of contact with the various elements of European and Asian protoindustrial technology, did not adopt these new technologies. It was a period when Africans knew what they wanted, why they wanted them, and how to organize themselves around their needs. For these purposes, skills were created and innovations made. Articles were adapted through ingenious means and people rewarded based on their ingenuity. Even explorers envied and praised the organizational strategies in their ingenuity as well as the levels of their productions. Yet, this was not a period of social cohesion but a society in flux but these changes were internally generated and managed. Thus, there were rises and falls of empires as it was in the other parts of the world (Olutayo, 1995). It involved competition, conflict, accommodation and assimilation all of which, in them, required certain levels of ingenuity (Olutayo \& Omobowale, 2006). Indeed, it was the extent to which these processes were managed that defined the sustainability of these societies and various itan carved around their existence. And it was what the royalty, as was the case in most African societies, in subordinating other members, were adept at doing by successfully making them forget the beginnings and creating '...a firmly established article of faith that one must be subservient and submissive to them...'(Khaldun,1967: p.314). Ironically, these were not perceived by European writers as they attempted to create a world suitable to the mission of the reigning expected interpretations of their times-end of slave trade. But this was further elaborated by the dominance of trade necessitated by the need for raw materials, the arguments for which were couched under the civilizing mission thesis. It was either through the use of force or the threat of its use. Hence, the emergence and justification of the third stage, the colonial era.

\section{The Colonial Intervention: The Subordination of Indigenous Knowledge and Creativity}

Perhaps the aspect of African history to which attention has been mostly drawn, especially with the assistance of Africans in Diaspora and the eventual independence movements, is the colonial intervention in the activities of Africans and their development experience. It captures the extent to which distortions of historicism are increased by the trusting and the selective use of verifying procedures in arriving at a utopian vision and inferring human behaviour from societal systems which are themselves, in the words of Hopkins (1980, p.150), 'mythical constructs'. Within these constructs, societies were placed based on preconceived categories without recourse to the histories of these societies. This was what characterized even sociological writings of the Parsonian era in the 1950s and '60s. Also, Marxist writings recognized a straight line development pattern with the history of the Western world show- 
ing the course of development for 'backward' areas of the world. It was not therefore surprising that the Cold War did not make a difference in the societies of the Third world as what was envisaged was the aping of their benefactors.

Perhaps of most significance was the Scramble for Africa and its eventual colonization. The former was justified, for the 'scrambled', by the arguments of 'protection' and the latter by the need to 'civilize' the uncivilized in European understanding. Of fundamental relevance in the latter that has contributed to the subordination of African knowledge and creativity was formal education, certificates or 'meal tickets' for which could only be individually attained.

Deriving from the Greek word of educere-meaning to bring out of darkness to light, colonial education defines the relevance of new type of knowledge, not only about how ways of life are structured but the means through which such ways are informed. Colonial education was meant to give strength to the physical force of domination through a mental control of the colonized. The mental control, implemented through the formal school system, according to Kelly and Altbach $(1984$, p.2), helped the colonialists to '...extend foreign and economic exploitation of the colony' by creating a new thinking pattern stripping the colonized of their indigenous learning structures of group existence and recommending, indeed, forcing them, to adopt the colonizers' mode of thinking based on individuality. It meant a change from traditional to a universal religion requiring a psychological transformation through which each convert's underlying assumptions of the world are reconstructed, accompanied by a socially recognized display of change (Carmody, 1988).

In fact, in places where religious education preceded the intervention of the colonial government, the 3R's - reading, writing and arithmetic, was conditioned on the knowledge of the bible. As Southard (1997) summarises it, colonial education 'leaves those colonized with a lack of identity and a limited sense of the past....The colonized become hybrids of two vastly different cultural systems'. Even in special circumstances where, due to the exigencies of international war, as in the Phelps-Stokesism in Central Africa, practiceoriented, community-centred approach to colonial education was derived from the educational concepts for African-Americans in the United States (Kuster, 2007), it was still knowledge based on imported understanding in so far as the experience of the Africans in America could not be said to reflect, totally, what was on ground in Africa (Hinojosa \& Park, 2004).

Furthermore, the implementers were not African themselves but the second hand knowledge producers of African way of life. Indeed, the reactions of the newly created knowledge groups in Africa was a furtherance of the new social structure undermining the indigenous structure of learning from which they saw themselves profiting and about which they were encouraged through the modernization perspective to which they were exposed. To show the importance of the difference in local and modernized Africans in their perception, the work of Araya and GebreMichael (2006) on the two groups' different pers- 
pectives have shown that most 'educated' people in agricultural research and development understand little about what interests smallholders. As such, they do not know what farmers want so as to give their time to see. Expectedly therefore, they do not observe how farmers are developing their own innovations and what type of information to seek from others to continue their own development process.

As far as the new knowledge structure inherited from colonialism was concerned, Africans' newly educated elites learnt the need to subordinate their indigenous ways of life since the new ways of doing things required new orientation to life. It entailed an association of European technology with individual achievement in formal education and definite advantages attached to doing things in a 'new' way (Bassey, 1991). Furthermore, the ultimate purpose of trade, as enunciated in the works of T.F. Buxton (1839), which was meant to 'call forth her (Africa's) own resources' (p.282), was attractive to the new African elites as the article of differentiation between them and the indigenous peoples were now relocated. Consequently, their requests for independence were with a view to reproduce 'White power' which they would administer over their people. In short, the restructuring of African social system involved a fundamental transformation in its entirety and accessible through European formal education. Skills and knowledge creation was reoriented to the four walls of the educational system rather than a life-long process learnt by imitation and trial and error in the environment. Education, defined as the acquisition of knowledge and skills, which used to be a product of the immediate environment, became something that had to be bought from outside the system as the system is now extended far beyond the immediate territories (Prakash, 2003). A clear example, though not of African extraction, is the abandonment of raised fields in the irrigation of agricultural production, even though an assessment of the effectiveness of this method identified many benefits of implementing the technique in agricultural production. Due to new economic exigencies however, farmers had abandoned the method for wage labour elsewhere (Middleton, 2007). It was this kind of forced eviction of Africans from the land, with the introduction of taxes and other colonial government assignments, which distracted the people from their indigenous socio-economic livelihoods.

Unfortunately, though not unexpected, the neo-colonial responses have witnessed a perpetuation of the colonial trend (Olutayo, 2002). Even when some indigenization attempts were made, they were always superficial. This was further compounded by the 'Cold war' which created a lot of tension all over the world (Engel, 2003; Fieldhouse, 1984). The United Nations (UN), mainly under the influence of the United States and Britain, declared the development decades for the $60 \mathrm{~s}$, '70s and ' $80 \mathrm{~s}$, depicting numerous programmes and projects, devoting numerous amounts of money recommending the provision of what has become known as 'basic survival necessities' without which human beings are thought not to be able to live or do without. Multiplicity of conferences, sponsored by these organizations, for transforming 
the Third world, have been sponsored to give recognition to these process. The Structural Adjustment Programme (SAP) is the latest in the prescriptions of the UN/World Bank/IMF. And, in the words of Makhubu (1995), former ViceChancellor of the University of Swaziland:

It is estimated that thousands of so-called experts, fielded by both governments of developed countries and NGOs and engaged in a variety of activities, still remain in Africa today. This has led many analysts to conclude that efforts at developing Africa have been propelled mainly from outside the African continent, and are in most cases based on foreign concepts. To the extent that endeavours at developing African countries have lacked indigenous nurturing, participation of stakeholders in their conception, and have been mainly donor-driven, this criticism is on the whole valid. Consequently, many donor-financed projects and programs have failed to take root and effectively contribute in a sustained and sustainable manner to the widespread advancement of the peoples of Africa....Quite frequently, the dearth of indigenous skills in the design of projects has reinforced the poor performance of development aid....This is Africa's development dilemma (in the)... $21^{\text {st }}$ century (my addition in brackets).

As stated elsewhere (Olutayo, 2002), the number of graduates from the primary, secondary and tertiary levels of education has continued to increase to the extent that governments all over Africa have been faced with both unemployment problems and the capacity to satisfy the increasing demand for formal education. Ironically, these nations are further encumbered with the quality being produced as the market for which the graduates are being produced change faster in its imported technology requirements than the rate at which governments could replace these technologies. Indeed, the cost of retraining even their teachers and lecturers has continued to be enormous, many of whom may still brain-drain due to bad socio-economic conditions in Africa more so where their professions are not limited to Africa (InterAcademy Council 2004; Cornish, 2005).

In all, Africans spend a far higher relative amount on each university student trained than does the U.S. or Europe (http://www.arp.havard.edu/ AfricaHigherEducation/Economics.html accessed 27th September, 2007). According to Muula, Panulo Jr and Maseko (2006), the total cost of training an enrolled nurse-midwife from primary school through nurse-midwifery training in Malawi was estimated as US\$9,329.53; for a degree nurse-midwife, the total cost was US $\$ 31,726.26$. And, for each enrolled nurse-midwife that migrates out of Malawi, the country loses between US\$71,081.76 and US\$7.5 million at bank interest rates of $7 \%$ and $25 \%$ per annum for 30 years respectively. For a degree nurse-wife, the lost investment ranges from US $\$ 241,508$ to US $\$ 25.6$ million at $7 \%$ and $25 \%$ interest rate per annum for 30 years respectively. In fact, these figures may be underestimated when compared to the report of 
Rumajogee (2003), the UNESCO consultant to the Republic of Seychelles, in which the training of one local specialist in IT in education costs US\$20,000, the same as for training one technician for three months overseas. This concern for innovation and its costs was raised among participants at the OECD Forum 2007 on Innovation, Growth and Equity as civil societies and trade unions identified the social disruptive effects of innovation as well as the illpreparedness of workers for changes that arise from innovations, in the so called developed world. This is more so for Africa where all the equipments would be imported from these foreign countries and the adaptation, including the training of the workers for its use, may still require the employment of foreign consultants.

\section{Which Way Out?}

Most especially with the existing socio-configurations of the world, including Africa, it seems as if Africa is doomed to perpetual knowledge subordination. The top-bottom approach has ensured the cob-webbed stringing of creativity and knowledge production. And, in spite of the World Bank's acknowledgement of innovations and ingenuity among the indigenous peoples, the extent to which indigenous knowledge production is made relevant in development process is doubtful. This assertion is against the backdrop of recent developments relating to the privatization of knowledge in the World Trade Organizations' activities. In fact, the attempts in the indigenous knowledge research, it seems, is mainly in searching for appropriate means by which knowledge producers can be rewarded. In short, knowledge for how much rather than knowledge for the understanding of the environment and the betterment of human societies is not given priority. Knowledge for how much involves competition which Africans seem incapacitated at, most especially because it requires that some would always want to profit even where they did not sow. Furthermore, the pace at which knowledge production is going does not give much hope for the indigenous knowledge structures of the World Bank to catch up given the intense competition at world levels. As such, research into knowledge productions has also transcended the universities, whether employed in the academics or 'industrial research laboratories'. More especially, also, is the fact that the knowledge produced in these arenas is 'pigeon-holed' in strait-jackets making innovations in research difficult and dictated by terms set up by 'established' paradigms. Unfortunately, what some researchers then do is to ensure a semblance with these paradigms to get their works published, the amount of which now dictates the pace of promotion.

Perhaps, one way out is to create the 'culture' of research at all levels of the society, including at the formal and informal levels of society. What needs to be rewarded here would be the extent to which people, in groups, produce new ways of doing things based on the understanding of their situations without any formal structure. Indeed, this has been the situation in most societies of Africa where the majority of the citizens do not really have any direct linkage to established structures. Thus, they live based on their social 
constructions of realities determined by the social and economic exigencies rather than depending on typologies. By implication it entails de-emphasizing the formal education structures since learning extends beyond the four walls of any institution. Thus, there is a need for 'book-knowledge' to give place to 'reasoning' capacities.

A starting point may be at the level of industry. Industries may have to pool their resources together with a view to creating the culture of innovation and technology by changing entrenched attitudes (Pietrobelli, 2006), including individualism and competition-which they can hardly afford. This may also be encouraged in formal and informal educational institutions wherein it is not the best individual that is being rewarded but the ability for groups to perform as a team, targeting the accomplishment of creating or recreating any form of technology (Olutayo \& Omobowale, 2007). This may also be extended to other areas of societal endeavour in recreating what was lost in colonialism.

\section{Conclusion}

'Received knowledge' is the bane of Africa's development and, without a fundamental transformation of the existing social structure, the underdevelopment process would continue to manifest. Interestingly, knowledgebased competition in today's global world has informed fundamental restructuring of education the world over and such transformations are not engendered only by governments but by the people. As such, it is not the government but the ability of the people to realize the need to survive within the context of new social realities. The transformation therefore includes those who categorize, or are categorized, as 'private' industrialists/entrepreneurs realizing their limitations in the WCE and taking steps to confront their socioeconomic and political situations. It is only then that the people can decide what happens in the educational and other levels of social institutions, including the political sphere wherein governments are expected to be representatives of both the peoples and their wills.

Of utmost importance is the urgency to restructure the universities in developing nations from their elitist 'ivory tower' orientation towards ensuring their relevance to the needs and interests of the society in which they live. This is, perhaps, why the editorial of Science and Development Network of $2^{\text {nd }}$ October 2007 suggests that:

If the universities are to meet the new expectations (of funding agencies), a fresh model is called for that reflects and responds to the needs of the world around them...Finally, greater openness requires improved communication beyond the academia in the 'new look' universities. A reluctance to communicate with the private sector, with policy makers, or with the wider community is one of the biggest failures of the 'ivory tower'. Universities that ignore this are in danger of sharing the same fate as a much earlier type of dinosaur. 
Of course, this would be enhanced when knowledge is redefined in terms of how the people perceive it and when they are, indeed, able to define their needs by themselves rather than being dictated to by others far removed from their environment. Indeed, it is only then can one talk of a true independence and, more importantly, when knowledge the world over can be better improved to assist mankind.

\section{References}

Altbach, P.G.2007.'The Imperial Tongue: English as the Dominating Academic Language' International Higher Education, Number 49, pp.1-4. Araya, H \& GebreMichael, Y. 2006. 'Endogenous and Modern Innovations: Differing Perspectives' IK Notes, No. 96, September pp.1-4.

Bassey, M.O.1991. 'Missionary Rivalry and Educational expansion in Southern Nigeria, 1885-1932' Journal of Negro Education, Vol.60, No.1, pp.36-46.

Bloom, D, D. Canning \& K. Chan, 2006. Higher Education and Economic Development in Africa (Africa region: Human Development Sector).

Boron, A.A. 2004. 'Promoting Poverty as a means of Creating Wealth' Editorial in Comparative Research Programme on Poverty, ISSC, Vol.11, No.1 (Feb.) p.3.

Bourner, T. 1998. 'More Knowledge, new knowledge: the impact on education and training' Education+ Training, Vol. 40, Number 1, pp.11-14.

Buxton, T.F. 1839. The African slave trade and its remedy (London: Frank Cass).

Carmody, B. 1988. 'Conversion and School at Chikuni, 1905-39'. Africa, Vol.58, no.2, pp.193-209.

Cornish, J.J. 2005. 'Blair; the colonial governor?' Mail and Guardian (June 13). South Africa.

Donnelly-Roark, P. 1998. 'Indigenous Knowledge Systems in Sub-Saharan Africa: An Overview' IK Notes, No. 1, October, pp.1-4.

Engel, J. 2003. 'Lives and Consequences: The Local Impact of the Cold War' A Conference Report http://www.wilsoncenter.org/index.cfm?fuseaction=e \&ents.print accessed $26^{\text {th }}$ September, 2007.

European Investment Bank. 2006. Economic Report on Partner Countries: a report by the Development Economics Advisory Service (DEAS)(July)) http://www.bei.org/cms/htm/fr/eib.org/attachments/deas_report_2006_en.p df accessed $6^{\text {th }}$ July, 2007.

Fieldhouse, R. 1984. 'Cold War and Colonial Conflicts in British West African Adult Education, 1947-1953' History of Education Quarterly, Vol.24, No.3, (Autumn), pp.359-371.

Fred-Mensah, B.K. 2003. 'Adzina: An Indigenous System of Trial by Jury on the Ghana-Togo Border' IK Notes, No. 59, pp. 1-4. (August).

Guyer, J.I. 1996. 'Traditions of Inventions in Equatorial Africa' African Studies Review, Vol. 39, No.3 (Dec.) pp.1-28. 
Hinojosa, V.J \& J.Z. Park, 2004. 'Religion and the Paradox of Racial Inequality Attitudes' Journal for the Scientific Study of Religion, Vol.43, No.2, pp.229-238.

Hopkins, A.G. 1980. 'Africa's Age of Improvement', History in Africa, Vol.7, pp.141-160.

IMF. 2007. IMF Survey: African Growth to edge Higher in 2007 (April 23 ${ }^{\text {rd }}$ ) http://www.imf.org/external/pubs/ft/survey/so/2007/NUM051A.htm accessed $22^{\text {nd }}$ September, 2007

InterAcademy Council. 2004. Realizing the Promise and Potential of African Agriculture (Amsterdam: InterAcademy Council)

Kelly, G.P \& P.G. Altbach, 1984. 'Introduction: The Four Faces of Colonialism' in G.P. Kelly \& P.G. Altbach (eds.) Education and the Colonial Experience (New York: Transaction) pp.1-5.

Khaldun, I. 1967. The Muqaddimah: An Introduction to History, Vol.3 (New York: Bollinger Series XLIII and Princeton University Press).

Knight, J. 2006. Higher Education Crossing Borders: A Guide to the Implications of the General Agreement on Trade in Services (GATS) for Cross-border Education - A Report Prepared for the Commonwealth of Learning and UNESCO (Canada and Paris: COL/UNESCO).

Kopytoff, I. 1981. 'Knowledge and Belief in Suku Thought' Africa: Journal of the International African Institute, Vol.51, No.3, pp.709-723.

Kreis, S. 2007a. 'Lecture 2: The Medieval World View (1)' The History Guide: Lectures on Modern European Intellectual History http://www. historyguide.org/intellect/lecture2a.html, accessed $7^{\text {th }}$ Sept. 2007.

Kreis, S. 2007b. 'Lecture 6: The Medieval Synthesis and the Secularization of Human Knowledge: The Scientific Revolution, 1543-1642 (1)' The History Guide:Lectures on Modern European Intellectual History http://www. historyguide.org/intellect/lecture6a.html accessed $7^{\text {th }}$ Sept. 2007.

Kuster, S. 2007. "'Book Learning" versus "Adapted Education": The Impact of Phelps-Stokesism on Colonial Education Systems in Central Africa in the Interwar Period' Pedagogica Historica: International Journal of the History of Education, Vol. 43, no.1, pp. 79-97.

Leonard, K.L. 2001. 'African Traditional Healers: The Economics of Healing' IK Notes, No.32, pp.1-4. (May).

Makhubu, L.P. 1995. 'Africa's Development Dilemma on the eve of the $21^{\text {st }}$ Century: The Role of International Co-operation' Third Annual Hopper Lecture presented at the University of Guelph, Oct.24 and at McGill University on Oct.26.

Mauro, P and Ostry, J.D. 2007. IMF Survey: Who's Driving Financial Globalization? (August, 16th) http://www.imf.org/external/pubs/ft/survey/so/2007/NUM0816A.htm accessed $22^{\text {nd }}$ September, 2007.

Middleton, M. 2007 'Using traditional knowledge in economic development: The impact of raised field agricultural production in Puno, Peru' IK Notes, No. 99, January, pp.1-4. 
Muula, A.S, B. Panulo Jr, \& F.C. Maseko, 2006. 'The financial losses from migration of nurses from Malawi' BMC Nursing, Vol. 5, No.9, pp. 1-6.

Nwokeabia, H. 2006. 'Linking Agricultural Innovations to Knowledge Sharing in Africa' IK Notes January, pp.1-4.

Olutayo, A.O. 2002. 'Educational Institutions' in Shoremi, M.O and Oyekunle, A.A (eds.) The Social Structure of Contemporary African Societies (Ibadan, Nigeria: Kraft Books Limited) pp.81-92.

Olutayo, A.O. 1996. 'Age and Aging Process in Nigeria' in Oke, E.A and Owumi, B.E (eds.) Readings in Medical Sociology (Ibadan, Nigeria: Resource Development and Management Services Books) pp. 72-84.

Olutayo, A.O. 1995. 'Community and Social Change' in Agbonlahor, F.I and Olutayo, A.O (Eds.) Issues and Perspectives in Sociology (Ibadan, Nigeria: Sam Bookman) pp. 105-116.

Olutayo, A.O. 1994. 'Systemic source of 'working children' in Africa: The case of Nigeria' Childhood, 4, pp. 207-211.

Olutayo, A.O. 1991. The development of underdevelopment: Rural Economy of colonial Southwestern Nigeria, PhD doctoral thesis, University of Ibadan.

Olutayo, A.O \& A.O. Omobowale, 2007. 'Production, Processing and Marketing of export Crops for Rural Development: The Case of Cocoa in Nigeria' in K. Wohlmuth, C. Eboue, A. Gutowski, J. Afeikhena, T. Kneduk, M. Meyn, T. Mama (eds.) Africa-Commodity Dependence, Resource Curse and Export Diversification (Berlin: Lit Verlag) pp.295316.

Olutayo, A.O \& Omobowale, A.O. 2006. 'The Youth and the Family in Transition in Nigeria' Review of Sociology, Vol.12, No.2, pp. 85-95.

Pietrobelli, C. 2006. 'Policy Briefs: Fostering technological capabilities in subSaharan Africa' Science and development Network November, pp.1-6. Prakash, S. 2003. 'Nurturing Traditional knowledge Systems for Development' IK Notes October, No. 61, pp.1-4.

Randeria, S. 2005. Knowledge, Diversity and Governance http://www.essays 2030.ethz.ch/onlineversion/137-144.pdf accessed 20 ${ }^{\text {th }}$ September, 2007.

Rumajogee, R. 2003. Consultancy Building of Lead teacher Training Institutions in Sub-Saharan Africa-Seychelles. (UNESCO Consultancy Unit, Republic of Seychelles) ED/HED/2003/PI/42. March.

Science and Development Network. 2007. 'Editorials: Equipping universities to join the war against poverty' Science and Development Network, October.

Southard, J. 1997. 'Colonial education' http://english.emory.edu/Bahri/Education.html accessed $24^{\text {th }}$ September, 2007.

Silver, H.R. 1981. 'Calculating Risks: The Socioeconomic Foundations of Aesthetic Innovation in an Ashanti Carving Community' Ethnology, Vol.20, No.2 (April), pp.101-114.

Van Damme, D. 2002. Outlooks for the International Higher Education Community in Constructing the Global Knowledge Society. Report of the First Global Forum on International Quality Assurance, Accreditation and 
the Recognition of Qualifications in Higher Education- "Globalization and Higher Education" (Paris: UNESCO)

World Bank. 1998/99. Knowledge for Development (Washington, D.C: Oxford University Press)

Yai, O.B. 1993. "In Praise of Metonymy: The Concepts of "Tradition" and "Creativity" in the Transmission of Yoruba Artistry over Time and Space' Research in African Literatures, Vol.24, No.4, Special Issues in Memory of Josaphat Bekunuru Kubayanda. (Winter), pp.29-37. 